Tkachenko Tetiana,

Dr. of Science (Economics), Kyiv National University of Trade and Economics

ORCID: 0000-0003-4179-5869

Researcher ID: 1691782

Hladkyi Oleksandr,

Dr. of Science (Geography),

Kyiv National University of Trade and Economics

ORCID: 0000-0002-0600-0832

Romanchenko Tetiana,

Post-graduate student,

Vadym Hetman Kyiv National Economic University, Kyiv, Ukraine

ORCID: 0000-0002-1663-1945

\title{
SMART BUSINESS DEVELOPMENT IN UKRAINE (VIA THE EXAMPLE OF CHERKASY REGION)
}

SMART business development is studied through indicators of geopolitical and geoeconomical changes via the example of Cherkasy oblast (the central region of Ukraine) in order to determine the strategy of regional business improvement using global political and economic priorities. Cherkasy oblast was selected for the study because it is one of the pilot regions for implementation of the SMART business strategies.

The following methods were used in the course of the study: the system-structure analysis, spatial-comparative method, interpolation, correlation as well as descriptionstatistical method.

The proposed results of the study may be used in Ukraine as well as in the countries of the Eastern Partnership for development of effective strategy for SMART business improvement. The results of the study are intended for national and regional SMART businesspolicy, optimisation of SMART specialisation forrepresentatives of medium and small business, researchers dealing with regional development problems etc.

Keywords. SMART business, Cherkasy region, regional development, geopolitical and geoeconomical changes, regional business improvement.

Ткаченко Тетяна, Гладкий Олександр, Романченко Тетяна. Розвиток SMART-бізнесу в Украӥні (на прикладі Черкаської області).

Розвиток SMART-бізнесу в даному дослідженні визначається за допомогою показників геополітичних та геоекономічних змін на прикладі Черкаської області (центральний регіон України) $з$ метою оптимізації стратегії вдосконалення регіонального бізнесу з використанням глобальних політичних та 
економічних пріоритетів. Черкаська область була обрана для дослідження тому, щзо вона є однією з пілотних областей саме для реалізащії SMART бізнесстратегій в Україні.

У процесі дослідження були використані такі методи: системноструктурний аналіз, просторово-порівняльний метод, інтерполячія, корелячія, а також описово-статистичний метод.

Запропоновані результати дослідження можуть бути використані в нашій державі та в країнах Східного партнерства для розробки ефективної стратегії вдосконалення SMART-бізнесу. Результати дослідження призначені для забезпечення формування національної та регіональної політикив галузі SMART-бізнесу, для оптимізації SMART спещіалізаиї представників середнього та малого бізнесу, дослідників, щуо займаються проблемами регіонального розвитку тощчо.

Ключові слова: SMART бізнес, Черкаська область, регіональний розвиток, геополітичні та геоекономічні зміни, покращзення регіонального бізнесу.

Relevance of research topic. Current trends of business innovation development are characterized by huge development of SMART business that means overcoming regional disparities caused by environmental damage and deep crises due to poverty and gender inequality, unemployment, etc., as well as preserving the environmental, economic, social and socio-cultural benefits for the future generations. SMART business development can become a key element for achieving the sustainable development goals of the territory. To this end, in our opinion, it is necessary to study the potential of sustainable regional development in order to identify the territorial disparities and thereby to determine areas for implementation of the SMART business strategy in each separate district of the region, depending on the specificity of the identified territorial problems.

Formulation of the problem. The aim is to study the regional aspects of building the sustainable development potential of the region as a prerequisite for developing SMART business regional strategies on the example of Cherkassy oblast. This publication reviews the internal territorial problems of the region and indicators of ecological, economic, social and socio-cultural development of the Cherkasy region. Implementation of the SMART business strategies is one of the effective methods for improving the acute socio-ecological and economic problems in the region.

Analysis of recent researches and publications. One of the approaches to develop successful strategy of regional improvement on different territories is based on SMART business. It is very important for the balanced sustainable development of the country. This was confirmed by the research in 19 districts of Latvia. The research findings reveal SMART-specific activities, which allow implementing the sustainable development concept in rural areas, taking into account socio-economic development and territorial differences in the regions (Šipilova, 2017, pp. 82-105). 
Natural resources, human resources, goods and technology are unconditional factors of economic growth. However, innovation is yet another evident factor of economic growth providing opportunities. This should be taken into account in the regions trying to overcome the crisis (Kreslins, 2016).

SMART business is an approach of the European Union to achieve sustainable regional development. It involves close cooperation and dialogue between government, business, science and community, as well as a shared vision of the region's economic, innovative and scientific potential (Brzóska, 2012). The issues of SMART business are not the focus of only EU officials. This concept is presented in the works of Ya. Bzhuska, I Pick, P. David, D. Frey, B. Hol, M. Cardas, and G. Tobor including attempts to use it.

The SMART business strategy is the subject of discussion of the innovation policy and regional innovation systems. It is also an instrument of innovation policy for the growth of competitiveness and economic development in the region (Asheim, 2019, pp. 8-25).

The research discovered that creation of food industry centres based on the SMART business can be beneficial for the regional economic development in Australia (Esposto, 2019). Approaches to the SMART business strategy are used in the cohesion policy of the European Union for the period of 2014-2020. This experience is a unique example for industrial policy in modernization of the industrial sectors (Foray, 2018, pp. 1505-1520).

The study is aimed at identifying factors that best explain the effectiveness of regional innovation. Linear regressions as statistical methods are used for developing methodology. As a result, regions are divided into innovative, strong, medium and weak. Activities for improving innovation interventions in these regions are proposed (Farinha, 2018, pp. 2114-2124).

SMART business is very difficult to categorize because of its multidimensional nature. However, Poland has identified regional SMART business within the internal potentials of the regions. In total, 81 SMART businesses were identified. The SMART business study is based on the endogenous potential of the regions (Banski, 2018, p. 5-30).

SMART business makes it possible to overcome structural deficiencies in the European social market economy. This is stated in the Europe 2020 Strategy agenda. Also, this agenda specifies the importance of determining the key areas of the resource regions and their readiness for SMART business.

Universities and research institutions are drivers of innovation development in the regions. However, they do not pay enough attention to SMART business strategies (Vallance, 2018, pp. 219-238). Using the potential of universities can successfully affect the economy of the remote regions. The role of universities in the regional development is increasing with the actualization of SMART business in the EU (Kempton, 2015, pp. 489-496).

The SMART business strategy involves identifying links between technological areas in the region. This is necessary to identify the related industries in the region and 
to form regional ties with other regions (Iacobucci, 2016, pp. 5-28). For several years, key issues in the implementation of SMART business in the European Union focused on supporting entrepreneurship (Mäenpää, 2018, p. 20).

Business development is needed to maintain the balance of regional systems. It provides people with jobs and maintains optimal living standard in the region. However, there are a number of barriers for initiating businesses based on high technology of the fourth industrial revolution. Ineffective state support is the main barrier to the development of innovation business. Recommendations were developed for improving the condition of small and medium enterprises in Ukraine.

Presenting main material. Objective assessment of the SMART business development of the region included two main stages: selection of statistical information and rating assessment of the potential components of the SMART business regional development (Pokliatskyi, 2016).

Statistical information was selected and systematized from the data of the Main Department of Statistics in Cherkasy oblast for 2017-2018. The relevant statistical information was organized according to the following subsystems: economic, social, ecological, socio-cultural and demographic potential.

The economic subsystem included 8 indices characterizing production potential, small business, export-import potential, investment attractiveness and incomes of the population.The social sphere of the districts of the Cherkasy oblast was evaluated by 9 indices, characterizing such areas as consumption of goods and services, provision of housing to population, housing improvement and public utility services, education infrastructure, situation in the labour market and public health status. The ecological situation was assessed by four indices characterizing the level of air pollution, the waste management situation and a contamination level of water bodies.

Socio-cultural component included six main indices characterizing the state of infrastructure and tourism, criminal level and family well-being. Demographic potential was assessed by five indices characterizing population density, natural and migratory population movement, gender-age harmony, economic activity and working capacity of the population.

These indices were used to rate components of the sustainable development potential. As there are many indices pertaining to the components of the sustainable development potential and they have different dimensionalities the first step of the methodology is to perform their preliminary rationing (bringing into similar form). As a result of sequence scaling the districts receive weighting factors from 0 to 1 with dimensionality 0.05 and are sequenced from 1 to 20 for indicators-incentives and in a reverse order for indicators-disincentives.

Each group of indices was divided into five subgroups with high, upper middle, middle, lower middle and low indicators. Reducing these indicators into indices allowed estimating situation of the districts in comparison to each other in the oblast region.

The results of calculations of these indices demonstrate that by quantitative parameters all the districts of the Cherkasy oblast are located in each of these 
subsystems in the order of favourable level increase (decrease). The integral indices of SMART business development reflect the objective assessment of the business development, according to official statistics.

Economic component of the SMART business development is revealed through indices reflecting the economic conditions of the population, development of the social sphere and the capacity to meet the needs of the population (Pokliatskyi, 2016). In order to display the SMART businesseconomic component, the following indices were selected:

1. index of production potential calculated by the sales volumes (goods and services) in 2018 (millions UAH), the number of legal persons and economic entities in 2018;

2. small business index (the number of small businesses in 2018);

3. export-import potential index (export and import of goods and services (millions USD);

4. investment attractiveness index (investment in fixed assets, thou UAH);

5. population income index (average monthly nominal wage of full-time staff, $\mathrm{UAH})$

The highest values of the index of SMART businesseconomic component are observed in Cherkassy, Zolotonoshsky, Smiliansky, Kanivsky, KorsunShevchenkivsky, Zhashkivsky and Umansky districts of the region. Three leading districts are Cherkasky, Smelyansky and Zolotonosky.

At the same time the localization index of sales volumes of industrial products has inverse values: districts with low values of previous index of sales volume of services to population have high values of this index.

Human capital is a major factor in regional innovations. Innovations are not only technologies, but also a change in the people's lifestyle (Koprivsek, 2017, pp. 117-135).

The integral index of SMART business social factors development was calculated on the basis of the following indices:

1. index of consumption of goods and services (in market prices, UAH);

2. index of housing provision (calculated by average values of the total housing area per person in $\mathrm{m}^{2}$, in 2017);

3. index of amenities and public utilities condition. It is calculated by indicators of the dilapidated housing stock ( $\mathrm{m}^{2}$ of the total area), emergency housing $\left(\mathrm{m}^{2}\right.$ of total area), equipment of the housing with water supply (cold and hot), heating as of January 1, 2017 (share of the equipped total area);

4. index of education infrastructure. It is calculated by coverage of children with pre-school educational institutions (as a percentage to the number of children of the corresponding age); the number of students of general educational institutions per 10 thousand population; the number of students in higher educational institutions of I-IV accreditation levels in 2017;

5. the public health index. It is calculated by the mortality rate of children under the age of 1 year by cities and districts in 2018; 
6. index of the labour market situation. It is calculated by the indices of the registered unemployment rate (the number of citizens with the status of the unemployed during the reporting period, (persons in 2017) and occupational injuries (per 1000 employees).

According to the index of favourable social situation for SMART business development, the following districts with a favourable (Zolotonoshsky, Zvenigorodsky, Shpolyansky and Smilyansky) and unfavourable (Drabivsky, Chornobayevsky, Kamensky, Korsun-Shevchenkivsky and Mankovsky districts) social component were identified.

Ecological factor plays a very important role in shaping the potential of SMART business development. The highest indices of ecological favourability are in Drabivsky, Smiliansky, Lisyansky and Talnivsky districts. The most vulnerable ecological situation is in Kaniv, Zolotonoshsky, Cherkassy and Chigirinsky districts associated with indices of industrial development.

It is worse to note, that the northern areas of Cherkasy region demonstrate the highest indices of social well-being, which can be associated with bordering on the capital region. At the same time, the central and southern areas of the oblast have low social well-being indices which can be attributed to the remoteness from the capital region and proximity to the depressed and poor Kirovograd oblast. This situation plays a very important role for SMART business development in the region.

Conclusion. The following steps for encouraging changes in Cherkasy region are determined in the SMART business strategies:

1 - state support centred on innovations and development based on knowledge, problems and needs

2 - instruments are provided for attracting private investments to $R \& D$ area;

3 - regional and state authorities accept innovation approaches to development (Brzóska, 2012).

Study of the internal differentiation of sustainable development potential in the Cherkasy oblast has revealed the 'foci' of social, economic and environmental advantages or disadvantages among districts of the oblast region.

This stands for the need to consider this territorial inequality in developing SMART business strategy. Grouping of the districts of Cherkasy oblast allowed us to identify groups of districts according to the indices of the economic, social and ecological subsystems, each requiring recommendations for implementation of the SMART business strategy.

Material, social and intellectual assets concentrated in the industrial and educational institutions of strong regions are the foundation for SMART business. The Zolotonosky, Cherkasky, Smiliansky and Umansky districts belong to this category due to their high indices of the economic component. Active investment in innovations is proposed in these districts for private sector.

Typically, regional policy should strengthen the competitive industries. However, SMART business strategies are often aimed at supporting underdeveloped regions. These are Drabivsky, Gorodyshchensky, Lisyansky and Khrystynivsky 
districts because of their low indices of the economic subsystem. It is recommended to provide training for representatives of the local government to identify the potential of SMART business in the districts.

Kanivsky, Zlotonoshsky, Cherkasky and Chigirinsky districts demonstrate low indices of the ecological subsystem. These districts have high economic development indices. Consequently, economic development in these districts is achieved at the cost of environmental losses. Recommendations on implementing SMART businessstrategy in these districts include the use of environmental innovative technologies able to reorient industry for not only to increasing capital but also for preserving natural resource potential of region.

Human capital is a major factor in SMART business development. High indices of the social subsystem are observed in Chornobayevsky, Korsun-Shevchenkivsky, Kamensky and Mankivsky districts. For these districts it is recommended to develop the potential of national and cultural crafts in combination with innovations strengthening specifics of the national identity. Kanivsky, Zolotonoshsky, Cherkasky and Chigirinsky districts have low indices of human capital. These are the districts developed economically but weak in the social component. For these districts it is recommended to implement social programs for adapting the population to rapidly changing economic conditions. In particular, programs are proposed for adaptation of boarding school graduates, assistance to families in difficult living conditions, programs of providing housing for young families, programs for reducing unemployment.

Cherkasy oblast has two regional nuclei with high indices of economic development. These are Cherkasy and Uman. At the same time, these regional centres have weak internal territorial ties. An important way of overcoming the territorial disparities in the development of Cherkasy oblast with their acute socio-economic consequences is to form, implement and continuously improve the mechanism of stimulating business development in the context of SMART specialisation, which should be based on fostering the development of innovative green technologies, nature conservation levers and overcoming social and economic disparities at the basic territorial level.

\section{REFERENCES}

1. Asheim, B.T (2019) Smart specialization, innovation policy and regional innovation systems: what about new path development in less innovative regions? Innovation Volume 32, Issue 1, 2 January 2019, Pages 8-25.

2. Banski, J. Mazurek, D. (2018) SMART specialization and the internal potential of regions in Poland. Folia Geographica Vol.60, Is. 1, 2018, P. 5-30.

3. Brzóska J., Pyka J. Rozwój ekosystemu innowacji w Regionie w perspektywie 2020 roku [w:] J. Pyka(red) Nowoczesność przemysłu i usług - nowe wyzwania. TNOiK. - Katowice, 2012. 
4. Esposto, A.S. Abbott, M. Juliano, P. (2019) Growing Regions through Smart Specialization: A Methodology for Modelling the Economic Impact of a Food Processing Hub in Australia. Economic Papers

5. Farinha, L. Ferreira, J.J. Silveira, P. (2018) Smart specialization policies: innovative performance models from European regions. European Planning Studies Volume 26, Issue 11, 2 November 2018, Pages 2114-2124.

6. Foray, D. (2018) SMART specialization strategies and industrial modernization in European regions-theory and practice. Cambridge Journal of Economics Volume 42, Issue 6, 9 November 2018, Pages 1505-1520.

7. Iacobucci, D. Guzzini, E. (2016) The smart specialization strategy of Italian regions and links among technological domains. Scienze Regionali. Volume 15, Issue 3, 2016, Pages 5-28.

8. Kempton, L. (2015) Delivering smart specialization in peripheral regions: The role of Universities. Regional Studies. Vol. 2, 2015 - Issue 1, P. 489-496/

9. Koprivsek, M.V. (2017) Regional policy in the eastern Slovenia cohesion region-innovative open technologies (smart specialization). Podravina Volume 16, Issue 31, 2017, Pages 117-135

10. Kreslins, K. Stefenberga, D. (2016) Analysis of Kurzeme region development in the context of smart specialization strategy: Preliminary results. Engineering for Rural Development. - Volume 2016-January, 2016, Pages 1224-1229.

11. Mäenpää, A. Teräs, J. (2018) In search of domains in smart specialization: Case study of three Nordic regions. European Journal of Spatial Development Issue 68, 2018, 20p. DOI: 10.30689/EJSD2018:68.1650-9544

12. Pokliatskyi S.A. (2016) Living conditions of the population of large cities in Ukraine: social and geographical research. $-185 \mathrm{p}$.

13. Šipilova, V. Ostrovska, I. Jermolajeva, E. Aleksejeva, L. Olehnovičs, D. (2017) Evaluation of Sustainable Development in Rural Territories in Latgale Region (Latvia) by Using the Conception of Smart Specialization. Journal of Teacher Education for Sustainability Volume 19, Issue 1, 27 June 2017, Pages 82-105.

14. Vallance, P. Blažek, J. Edwards, J. Květoň, V. (2018) SMART business in regions with less-developed research and innovation systems: A changing role for universities? Environment and Planning C: Politics and Space Volume 36, Issue 2, 1 March 2018, Pages 219-238. 